\title{
Mimetit z ložiska Ján Nepomuk pri Vel'kom Poli (Slovenská republika)
}

\section{Mimetite from the Ján Nepomuk deposit near Vel'ké Pole (Slovak Republic)}

\author{
Martin ŠteVkoo ${ }^{1,2) *}$, Peter Toth $^{3)}$, Filip LednickÝ4), JiŘí SeJKora ${ }^{2)}$ a ZdenĚK Dolníček ${ }^{2)}$ \\ 1)Ústav vied o Zemi, Slovenská akadémia vied, Dúbravská cesta 9, 84005 Bratislava, Slovenská republika; \\ *e-mail: msminerals@gmail.com \\ 2)Mineralogicko-petrologické oddělení, Národní muzeum, Cirkusová 1740, 19300 Praha 9 - Horní Počernice,
} Česká republika

${ }^{3)}$ Katedra mineralógie, petrológie a ložiskovej geológie, Prírodovedecká fakulta, Univerzita Komenského v Bratislave, Ilkovičova 6, 84215 Bratislava, Slovenská republika

4) Pribinova 220/17, 95618 Bošany, Slovenská republika

ŠteVko M, Toth P, Lednický F, Sejkora J, Dolniček Z (2021) Mimetit z ložiska Ján Nepomuk pri Vel'kom Poli (Slovenská republika). Bull Mineral Petrolog 29(1): 1-5 ISSN 2570-7337

\begin{abstract}
A new occurrence of mimetite was recently discovered at the abandoned Ján Nepomuk Pb-Ag deposit near Vel'ké Pole, Žarnovica Co., Banská Bystrica Region, Slovakia. It forms light to bright yellow, prismatic crystals reaching up to $5 \mathrm{~mm}$ in size. Mimetite occurs in fractures and cavities of strongly altered and limonitised limestone with impregnations and relicts of primary galena and pyrite. It is associated with cerussite and calcite. The refined unit-cell parameters (for the hexagonal space group $P 6_{3} / m$ ) are a 10.2437(4) $\AA, c$ 7.4437(6) $\AA$ and $V 676.44(6) \AA^{3}$. Except of dominant contents of $\mathrm{Pb}, \mathrm{As}$ and $\mathrm{Cl}$ only minor amounts of $\mathrm{Ca}$ (up to $0.36 \mathrm{apfu}$ ), $\mathrm{Al}$ (up to $0.03 \mathrm{apfu}$ ), $\mathrm{P}$ (up to 0.03 apfu) and $\mathrm{V}$ (up to 0.02 apfu) were detected in four mimetite samples studied by EMPA-WDS.
\end{abstract}

Key words: mimetite, X-ray powder data, chemical composition, supergene minerals, Ján Nepomuk deposit, Vel'ké Pole, Píla, Slovak Republic

Obdrženo 5. 2. 2021; prijato 3. 5. 2021 